Paper 11 of 18

\title{
Population Dynamics of the Giant African River Prawn Macrobrachium vollenhovenii Herklots 1857 (Crustacea, Palaemonidae) in the Cross River Estuary, Nigeria
}

\author{
F. M. Nwosu ${ }^{1 *}$ and M. Wolfi ${ }^{2}$ \\ ${ }^{1}$ Institute of Oceanography, University of Calabar, P.M.B 1115, Calabar, Nigeria. \\ E-mail: fmnwosu@yahoo.com \\ ${ }^{2}$ Centre for Tropical Marine Ecology (ZMT), Fahrenheitstrasse 6, D-28359, Bremen, Germany \\ *Corresponding author
}

\begin{abstract}
Growth, mortality, recruitment, yield-per-recruit and present rate of exploitation of the African river prawn Macrobrachium vollenhovenii were studied in the Cross River Estuary, Nigeria. The research was based on length-frequency data collected between January 1997 and June 1998, and FAO-ICLARM Software (FiSAT) routine runs. Growth parameters obtained from the seasonalized von Bertalanffy growth function were $\mathrm{L} \infty 213.63$ and $198.99 \mathrm{~mm}, \mathrm{~K}=1.24$ /year and 1.24/year; $\mathrm{C}=0.95$ and 0.95 ; $\mathrm{WP}=0.6$ and 0.45 , for $M$. vollenovenii males and females, respectively. Using the seasonalized length-converted catch curves, the instantaneous rate of total mortality Z was estimated as 3.93/year and 6.85/year for males and females. Natural mortality M, fishing mortality F, and exploitation rate $\mathrm{E}$ of both sexes were 2.21/year and 2.27/year, 1.72/year and 4.58/year, and 0.44 and 0.67 , respectively. The length at first capture $\mathrm{L}_{c}$ estimated from the probability of capture routine was $44.25 \mathrm{~mm}$ and $73.41 \mathrm{~mm}$ for males and females. One recruitment peak was observed for males, and two of unequal strength for females. Length-weight relationship gave ' $b$ ' values of 3.483 and 3.329 for males and females, respectively. The relative yield-per-recruit analysis predicted maximum exploitation rates $\left(\mathrm{E}_{\max }\right)$ of 0.42 and 0.47 as against current exploitation rates of 0.44 and 0.67 for males and females and suggest that only female $M$. vollenhovenii are being over-exploited. Hence, it is proposed that fishing on females during the reproductive season is reduced, and that the return of egg-bearing females into the waters is enforced.
\end{abstract}

\section{Introduction}

Macrobrachium vollenhovenii Herklots is endemic to the eastern Atlantic, with viable fishery in most of the countries in the West African sub-region. Gabche \& Hockey (1995) reported its growth and mortality in Cameroon, while Bello-Olusoji \& Somers (1997) studied its distribution in Western Nigeria. Etim \& Sankare (1998) studied the population dynamics of the species in Fahe River, Côte d'Ivoire. Marioghae (1982) reported on aspects of its biology and distribution in the Lagos lagoon. Due to its large size (specimens of 19 cm have been recorded in samples (Nwosu, 2000). Willführ-Nast et al. (1993) has recom-mended this species for aquaculture cultivation, as an African equivalent of the now widely cultured M. rosenbergii (FAO, 2000). Though freshwater organism, the larvae of this species require brackish water for survival and early development (New \& Singholka, 1985). Egg-bearing females migrate from freshwater to the estuarine areas to spawn. This accounts for the heavy exploitation of the species during the reproductive periods in the study area.

In the Cross River Estuary, the species is an important component of the artisanal Macrobrachium fishery, constituting about $37 \%$ by weight of the total catch. It is caught all year-round in association of other palaemonid species, with two peaks in May-June and November-December, which, incidentally, coincides with the peak of reproductive activity of the species. The fishery sustains more than 700 fisher families and supplies food protein to coastal dwellers.

One of the banes of tropical artisanal fisheries is management (Gulland, 1982). This problem may not be unconnected, among other things, with the lack of information as to the population biology of the species in question, which is essential for taking management decisions. The Macrobrachium fishery in the Cross River Estuary is not an exception. Information on the population parameters are scanty, especially for the species, M. vollenhovenii. Powell (1983) observed this problem and solicited for research.

The present study is the first report on the population dynamics of the species in the Cross River Estuary, Nigeria, and provides information on its management for sustainable exploitation.

\section{Materials and methods}


Specimens of $M$. vollenhovenii were collected from the commercial artisanal landings at Akpan's beach on the coast of Calabar (Fig. 1). Samples were taken weekly from January 1997 to June 1998 and were pooled into monthly data for further analysis. At the landing site, the total catch of a boat was sampled. Each sample was first sorted into sexes, and then length-frequency data was obtained by measuring individual shrimps by sizes (total length-from tip of rostrum to tip of telson) to the nearest $0.1 \mathrm{~mm}$. These were later grouped into 10 $\mathrm{mm}$ class intervals for analysis. Ten boats were sampled monthly, resulting in a total of 180 boats for the study period.

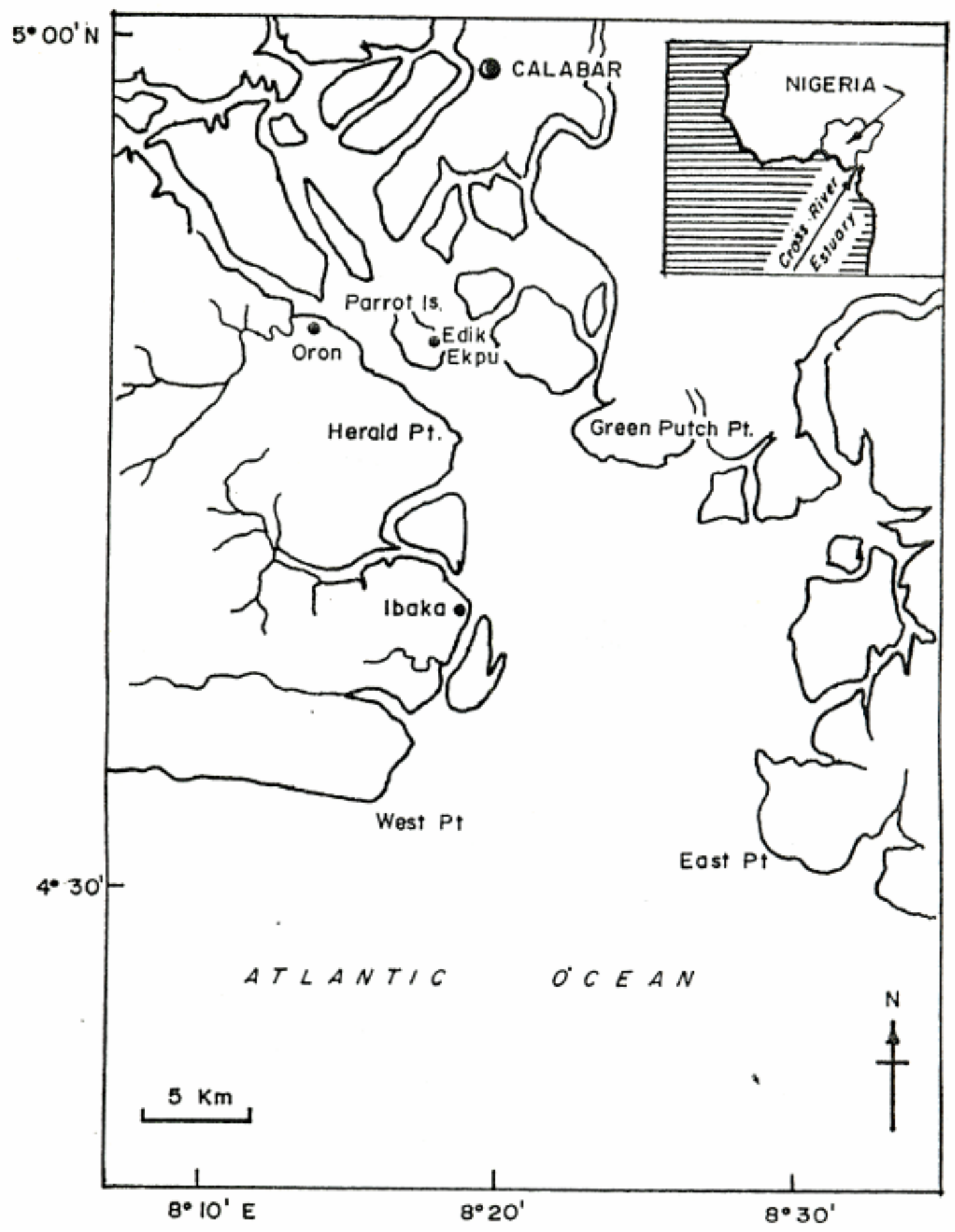

Fig. 1. The Cross River Estuary, Nigeria indicating Calabar the sampling station. 


\section{West Africa Journal of Applied Ecology (WAJAE) -ISSN: 0855-4307 \\ Volume 9 (Jan - Jun 2006) \\ www.wajae.org}

Growth analysis of the length-frequency data was carried out with the help of the FAO-ICLARM Stock Assessment Tools (FiSAT) edited by Gayanilo \& Pauly (1995). This composite incorporated the seasonalized version of von Bertalanffy growth equation (Bertalanffy, 1938), as modified by Pauly \& Gaschütz (1979), thus:

$\mathrm{L}_{\mathrm{t}}=\mathrm{L} \infty\left(1-\mathrm{e}_{\mathrm{o}}^{-\mathrm{K}\{(\mathrm{t}-\mathrm{t})+(\mathrm{CK} / 2 \pi) \operatorname{Sin}[2 \pi(\mathrm{t}-\mathrm{t})]\}}\right)$

where $L_{t}$ is mean length at age $t, L_{\infty}$ is asymptotic length (which is the mean length the fish or stock is expected to reach if it were to grow indefinitely); $\mathrm{K}$ is the growth constant, indicating the rate at which $\mathrm{L} \infty$ is approached; $t_{0}$ is "age" at zero length; $C$ is constant expressing the amplitude of seasonal oscillations in growth; and $\mathrm{t}_{\mathrm{s}}$ is phase of the oscillations-indicating the onset of oscillations, now replaced by Winter Pointtime of year when growth is slowest $\left(\mathrm{WP}=\mathrm{t}_{\mathrm{s}^{+}} 0.5\right)$ (Pauly, 1987; Pauly \& David, 1981). The ELEFAN I routine of FiSAT which allows the estimation of von Bertalanffy growth parameters without knowing the age of the individuals (Pauly, 1985) was used to estimate the growth parameters $\mathrm{L} \infty \mathrm{K}, \mathrm{C}$ and WP (Winter Point). This routine requires inputs of seeded $\mathrm{L} \infty, \mathrm{K}, \mathrm{C}$ and WP values. Initial seed value for $\mathrm{L} \infty$ was obtained using Taylor (1958) from the largest individual $\left(\mathrm{L}_{\max }\right)$ observed in the samples, thus:

$\mathrm{L}_{\infty}=\mathrm{L}_{\text {max }} / 0.95$

The $\mathrm{L}_{\max }$ observed in samples during this study were $190 \mathrm{~mm}$ and $159 \mathrm{~mm}$ for males and females, respectively. The estimates of $\mathrm{L}_{\text {, }}$ and $\mathrm{K}$ were used to compute the growth performance index $\nRightarrow$ ' of the species using Munro \& Pauly (1983), Pauly \& Munro (1984):

$$
\Phi^{\prime}=\log 10 \mathrm{~K}+2 \log _{10} \mathrm{~L} \infty
$$

and the longevity $\left(\mathrm{t}_{\max }\right)$ of the shrimps (Pauly, 1980a)

$$
\mathrm{t}_{\max }=\text { approx. } 3 / \mathrm{K}
$$

Total mortality (Z) was derived from the length-converted catch curve (Pauly, 1983), a component of ELEFAN I by fitting a regression line through the natural logarithm of the number $(\mathrm{N})$ of shrimps in various length groups divided by the time needed for an average individual to grow through the length class, against their relative age $\left(t^{\prime}\right)$. $(Z)$ was estimated from the slope $b$ (with sign changed) of the descending right arm of the plot, with seasonality accounted for:

$$
\ln (\mathrm{N})=\mathrm{a}+\mathrm{bt}{ }^{\prime}
$$

where $\mathrm{N}$ is number of shrimps in various length groups, $\mathrm{t}$ ' is the relative age.

Pauly's empirical formula (Pauly, 1980b) for natural mortality was used to estimate the natural mortality coefficient (M) for $M$. vollenhovenii, thus:

$\log _{10} M=-0.0066-0.279 \log _{10} L \infty+0.6543 \log _{10} K+0.463 \log _{10} T$

The mean ambient temperature used here was $26.7^{\circ} \mathrm{C}$ (Akpan \& Offem, 1993).

The fishing mortality $(F)$ was calculated from $F=Z-M$, and the exploitation rate (E) from $E=F / Z$.

Probabilities of capture were calculated from the ascending left arm of the catch curves which consists of incompletely selected and/or incompletely recruited shrimps. The method consists of backward extrapolation of the right descending side of the catch curve to include shrimps that ought to have been caught has it not been for the effect of incomplete selection and/or recruitment.

ELEFAN II routine of FiSAT was used to obtain recruitment patterns by backward projection onto time axis of the available length frequency data by means of growth parameters (Moreau \& Cuende 1991). The modified form of Beverton \& Holt (1964) relative yield-per-recruit (Y'/R) analysis by Pauly \& Soriano (1986) was used to estimate the levels of exploitation of M. vollenhovenii that would give optimum yields. From the analysis, $\mathrm{E}_{\max }$ (the exploitation rate giving maximum relative yield per recruit), $\mathrm{E}_{0.1}$ (the exploitation rate at which the marginal increase in relative yield-per-recruit is $10 \%$ of its value at $\mathrm{E}=0$ ), and $\mathrm{E}_{0.5}$ (the exploitation 


\section{West Africa Journal of Applied Ecology (WAJAE) -ISSN: 0855-4307 \\ Volume 9 (Jan - Jun 2006) \\ www.wajae.org}

rate corresponding to $50 \%$ of the unexploited relative biomass per recruit $\left(\mathrm{B}^{\prime} / \mathrm{R}\right)$ ), were estimated. The impacts on yields of changes of exploitation rate $(\mathrm{E})$ and length at first capture-asymptotic length ratio $\left(\mathrm{L}_{c} / \mathrm{L}_{\infty}\right)$ in relation to a change of mesh size was assessed using yield isopleths diagrams.

Length-weight relationship (LWR) was computed with the formula

$$
\ln \mathrm{W}=\ln \mathrm{a}+\mathrm{b} \ln \mathrm{L} \quad \text { 7) }
$$

T-test for departure from isometry was carried out using Pauly (1984)

$\mathrm{t}=$ s.d. $(\mathrm{x}) / \mathrm{s} \cdot \mathrm{d}(\mathrm{y}) *\left((\mathrm{~b}-3) / \sqrt{ } 1-\mathrm{r}^{2}\right) * \sqrt{ } 1-2$

8)

and tested at alpha level 0.05 .

\section{Results}

The monthly length-frequency data for this investigation are presented in Tables 1 and 2. The restructured form of the length-frequency data is presented as output of ELEFAN 1 in Fig. 2 and 3. Growth parameters for $M$. vollenhovenii males were $\mathrm{L}_{\infty}=213.63 \mathrm{~mm}, \mathrm{~K} /$ year $=1.24, \mathrm{C}=0.95$ and $\mathrm{WP}=0.60$ (July), while the females had $\mathrm{L}_{\infty}=198.35 \mathrm{~mm}, \mathrm{~K} / \mathrm{year}=1.25, \mathrm{C}=0.95$ and WP $=0.45$ (June). From these results, the growth performance index, phi prime $(\Phi)$ was 2.75 and 2.69 for the males and females, respectively, while longevity $\left(\mathrm{t}_{\max }\right)$ was 2.42 years and 2.40 years (approximately 29 and 28.8 months), respectively. The length-converted catch curves (Fig. 4 and 5) estimated the instantaneous rate of total mortality (Z) as 3.93/year, for males and 6.85/year for females. Natural mortality (M) was 2.21/year and 2.27/year, and fishing mortality (F) 1.72/year and 4.58/year. The exploitation rate (E) was thus 0.44 and 0.67 , for $M$. vollenhovenii males and females, respectively.

TABLE 1

Length-frequency data for M. vollenhovenii males (constant class interval of $10 \mathrm{~mm}$ total length) from the Cross River Estuary, Nigeria

\begin{tabular}{|c|c|c|c|c|c|c|c|c|c|c|c|c|c|c|c|c|}
\hline Mid length & F 97 & $M$ & $A$ & $M$ & $J$ & $J$ & A & $S$ & $O$ & $N$ & $D$ & J 98 & $F$ & $M$ & A & $M$ \\
\hline 25 & & & & & 2 & & 2 & 4 & 3 & 1 & 2 & 4 & & & 2 & \\
\hline 35 & & 3 & 1 & 3 & 7 & 11 & 4 & 7 & 29 & 24 & 45 & 47 & 17 & 5 & 6 & 4 \\
\hline 45 & & 4 & 1 & 14 & 12 & 13 & 5 & 35 & 34 & 33 & 51 & 42 & 26 & 7 & 8 & 69 \\
\hline 55 & 2 & 15 & 4 & 26 & 39 & 27 & 19 & 54 & 30 & 27 & 22 & 39 & 38 & 5 & 9 & 98 \\
\hline 65 & 4 & 16 & 8 & 30 & 52 & 30 & 20 & 34 & 17 & 28 & 19 & 51 & 69 & 7 & 7 & 111 \\
\hline 75 & 4 & 7 & 6 & 24 & 62 & 29 & 15 & 25 & 2 & 5 & 15 & 41 & 116 & 3 & 3 & 224 \\
\hline 85 & & 6 & 28 & 44 & 25 & 27 & 11 & 5 & 2 & & 15 & 26 & 104 & 5 & 1 & 124 \\
\hline 95 & & 8 & 40 & 26 & 32 & 39 & 12 & 5 & 4 & 11 & 9 & 16 & 136 & & 2 & 58 \\
\hline 105 & & 6 & 8 & 36 & 23 & 64 & 14 & 8 & 10 & 8 & 7 & 34 & 96 & 1 & & 66 \\
\hline 115 & & & 5 & 19 & 27 & 63 & 22 & 14 & 14 & 15 & 18 & 26 & 82 & 3 & & 44 \\
\hline 125 & & 4 & 4 & 25 & 39 & 24 & 5 & 6 & 15 & 18 & 9 & 20 & 50 & & & \\
\hline 135 & & & & 12 & 15 & 10 & 5 & 8 & 6 & 3 & 14 & 23 & 40 & 1 & & 1 \\
\hline 145 & & & & 12 & 14 & 10 & 5 & & 9 & 11 & 5 & 6 & & & & \\
\hline 155 & & & & & & & 3 & 1 & & 3 & 1 & 3 & & & & \\
\hline 165 & & & & & 7 & 2 & & & 1 & 1 & 2 & & & & & \\
\hline 175 & & & & & & & & & & & & & & & & \\
\hline 185 & & & & & & & & & & 3 & & & & & & \\
\hline
\end{tabular}

$\begin{array}{llllllllllllllllll}\text { Sum } & 10 & 69 & 105 & 271 & 356 & 349 & 142 & 206 & 176 & 191 & 234 & 378 & 774 & 37 & 38 & 799 & 95\end{array}$

Length- frequency data for M. vollenhovenii females (constant class interval of $10 \mathrm{~mm}$ total length) from the Cross River Estuary, Nigeria 


\section{West Africa Journal of Applied Ecology (WAJAE) -ISSN: 0855-4307 \\ Volume 9 (Jan - Jun 2006) \\ www.wajae.org}

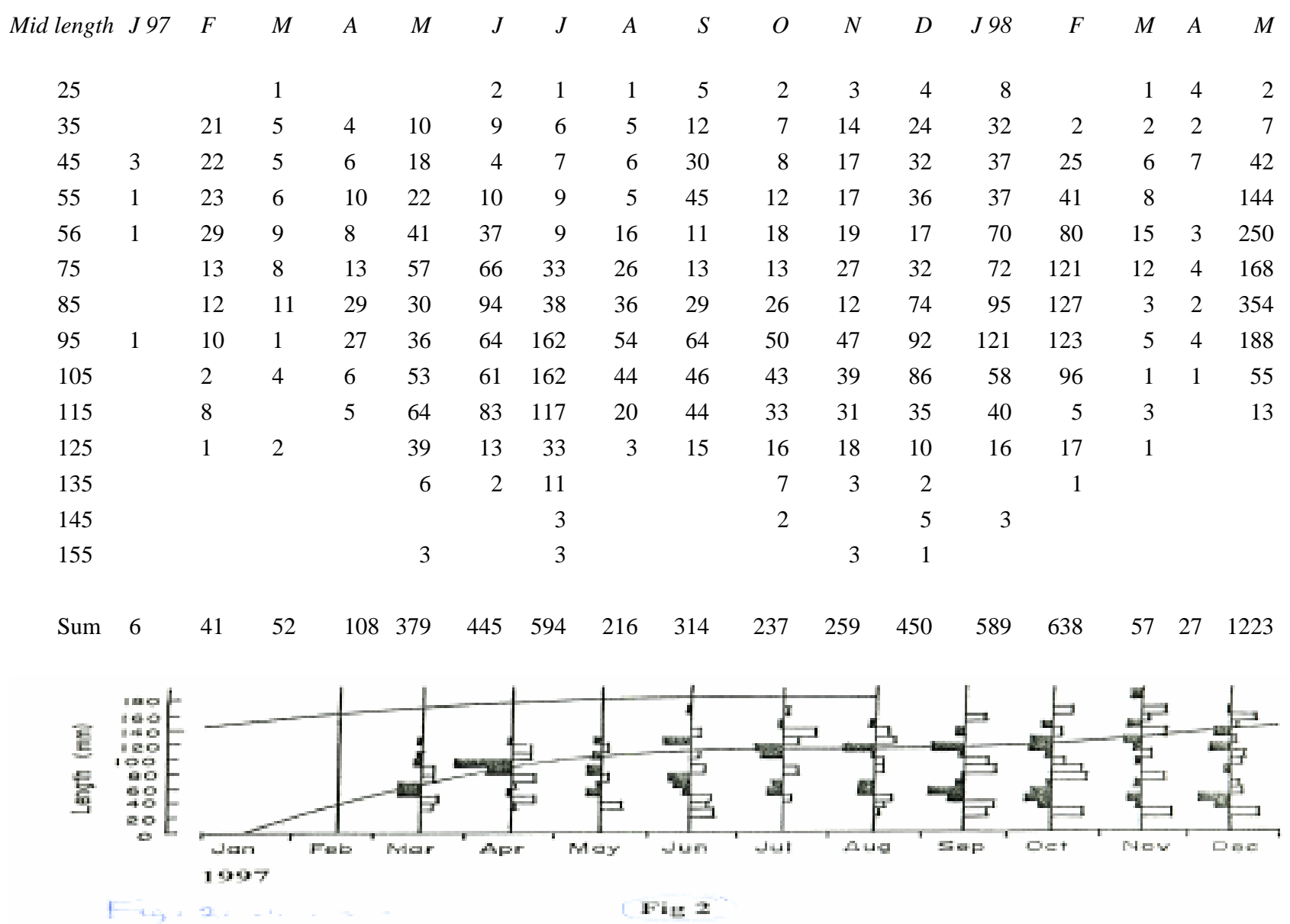

Fig. 2. Growth curve superimposed over the restructured length-frequency histograms for M. vollenhovenii males $(\mathrm{L} \infty=213.63$ $\mathrm{mm}$ (total length), $\mathrm{K}=1.24$ /year, $\mathrm{C}=0.95$, $\mathrm{WP}=0.60, \mathrm{Rn}=0.199$ )

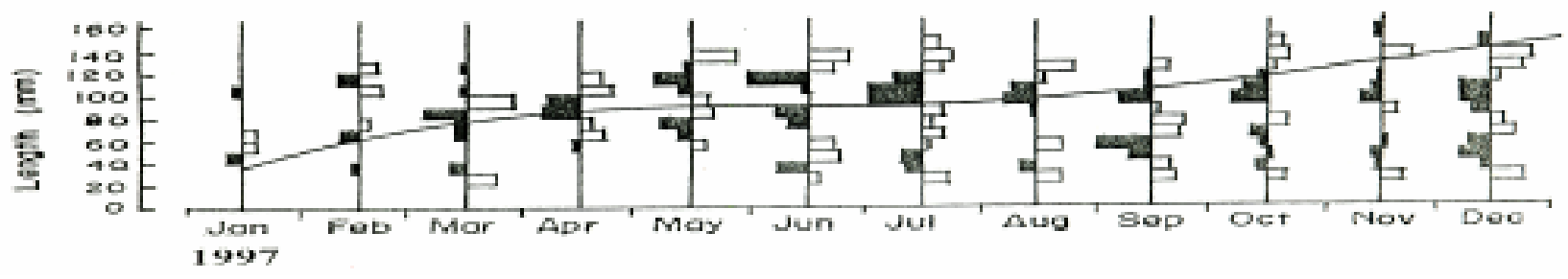

Fig. 3. Growth curve superimposed over the restructured length-frequency histograms for $M$. vollenhovenii females $(\mathrm{L} \infty=198.35 \mathrm{~mm}$ (total length), $\mathrm{K}=1.25$ year, $\mathrm{C}=0.95$, $\mathrm{WP}=0.45, \mathrm{Rn}=0.183$ ). 

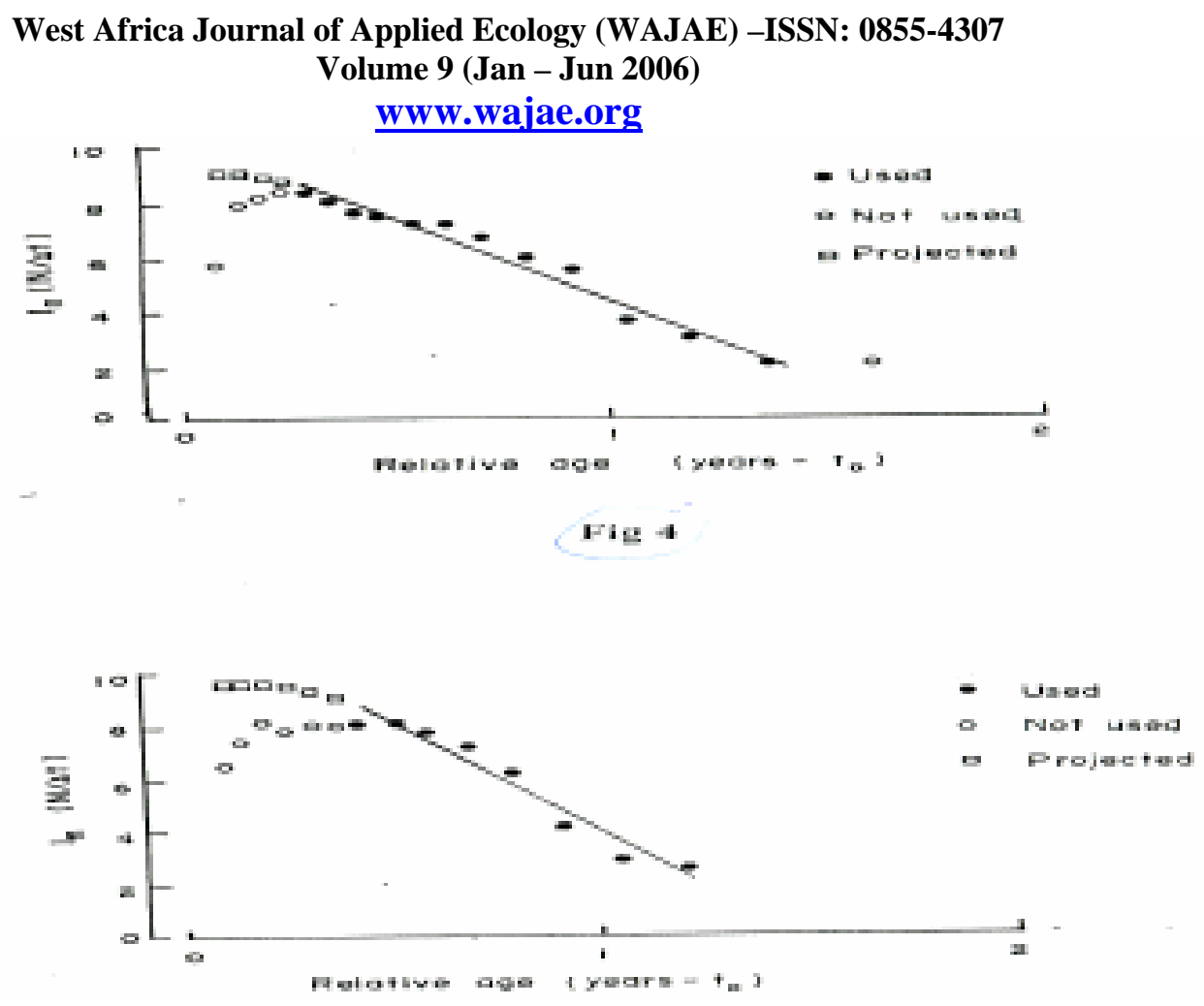

Fig. 4. Length-converted catch curve of $M$. vollenhovenii females of the Cross River Estuary, Nigeria. Estimated $\mathrm{Z}=3.93$ year.

Fig. 5. Length-converted catch curve of $M$. volenhovenii females of the Cross River Estuary, Nigeria. Estimated $\mathrm{Z}=6.85 /$ year.

From the probabilities of capture estimation, the length-at-first-capture $\left(\mathrm{L}_{c}\right)$ for $M$. vollenhovenii males was $44.25 \mathrm{~mm}$ (Fig. 6) while $\mathrm{L}_{\mathrm{c}}$ for females was $72.41 \mathrm{~mm}$ (Fig. 7). The size distribution of the catches suggest a single recruitment pulse for males, and two recruitment pulses of unequal magnitude for females (Fig. 8 and 9). Relative yield-per-recruit analysis using the selection give option of FiSAT gave $\mathrm{E}_{\max }=0.42, \mathrm{E}_{0.1}=0.4$, and $\mathrm{E}_{0.5}=0.27$ for $M$. vollenhovenii, males (Fig. 10), and $\mathrm{E}_{\max }=0.47, \mathrm{E}_{0.1}=0.45$ and $\mathrm{E}_{0.5}=0.29$ for the females (Fig. 11). Yield isopleths, giving $L_{c} / L_{\infty}$ ratios of 0.21 for $M$. vollenhovenii males and 0.37 for the females are represented in Fig. 12 and 13, respectively. The average rainfall (mm) over the study area (Calabar) and the percentage of egg-bearing females in samples were presented in Fig. 14.

Length-weight relationship of the form $\mathrm{W}=\mathrm{aL}^{\mathrm{b}}$ computed for both sexes gave $\mathrm{b}$-values of 3.483 (males) and 3.329 (females). The b-values were significantly different from $3\left(\mathrm{r}^{2}=0.993\right.$, $\mathrm{df}=1069, \mathrm{p}<0.05$ for males; and $\mathrm{r}^{2}=0.990, \mathrm{df}=1357, \mathrm{p}<0.05$ for females). 


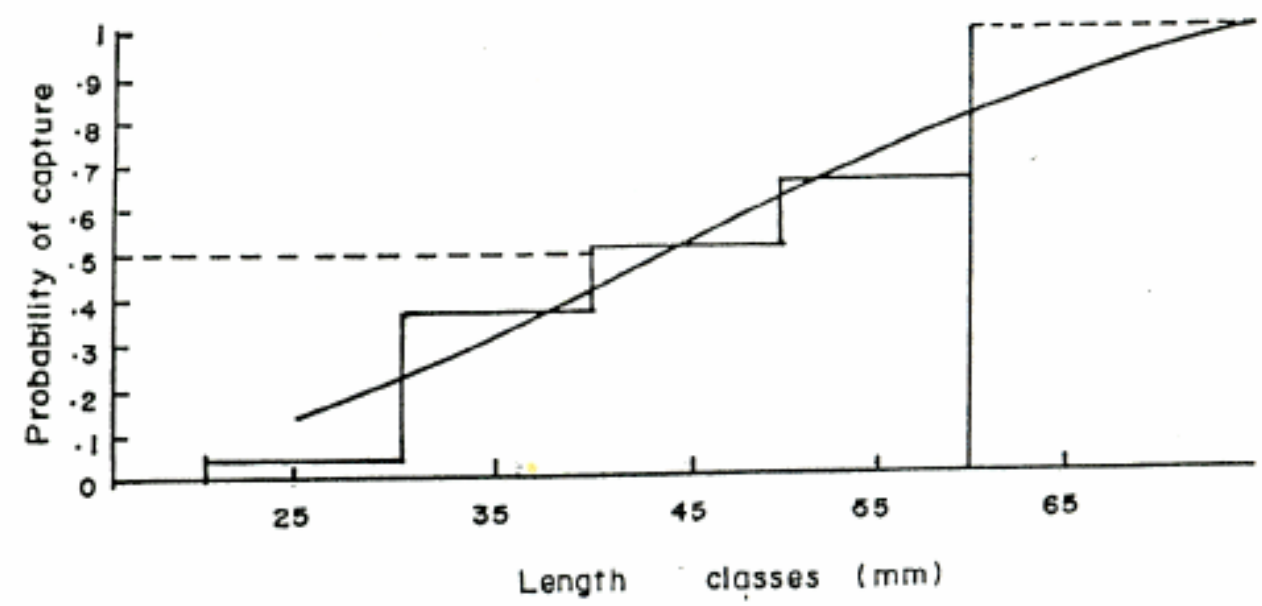

Fig. 6. Probability of capture of $M$. vollenhovenii males as estimated from the ascending arm of the catch curve. The length at first capture $(35.22 \mathrm{~mm})$ obtained from this procedure was on input data for the computation of relative yield per-recruit.

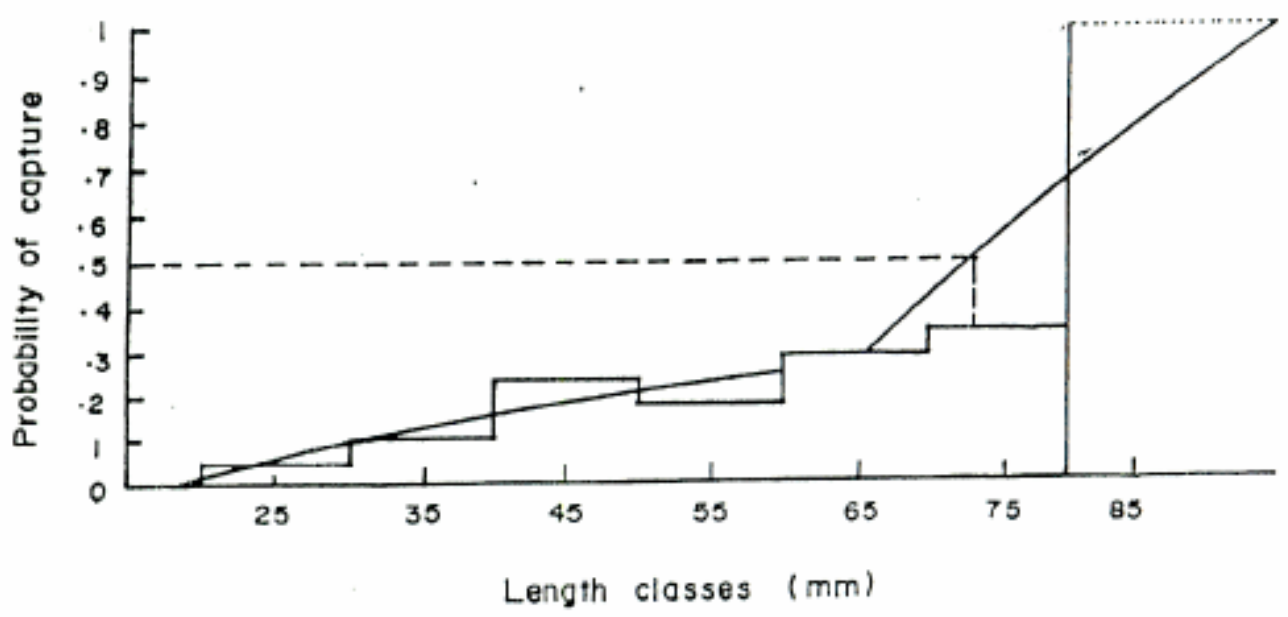

Fig. 7. Probability of capture of M. vollenhovenii females as estimated from the ascending arm of the catch curve. The length of first capture $(72.41 \mathrm{~mm})$ obtained from this procedure was an input data for the computation of relative yield per-recruit. 


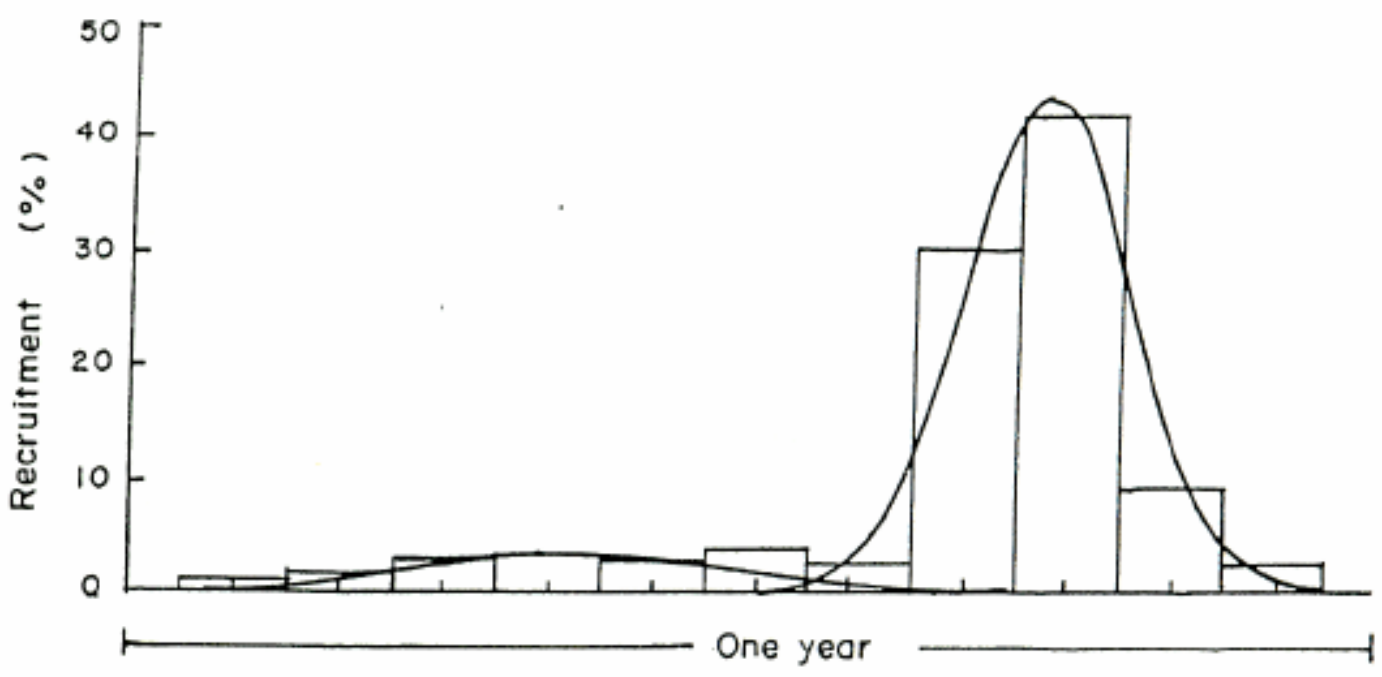

Fig. 8. Recruitment pattern of $M$. vollenhovenii males of the Cross River Estuary, Nigeria, indicating a single peak within an arbitrary year.

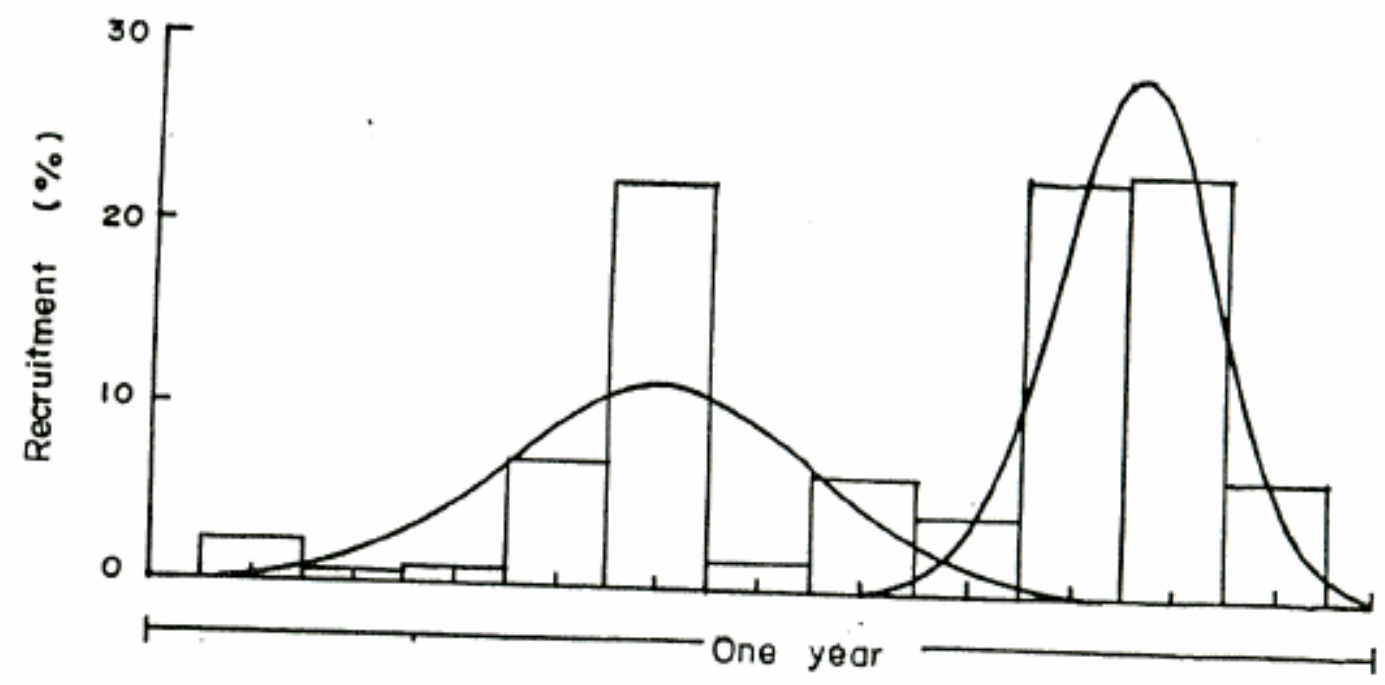

Fig. 9. Recruitment pattern of M. vollenhovenii females of the Cross River Estuary, Nigeria, indicating two peaks of unequal magnitude within an arbitrary year. 

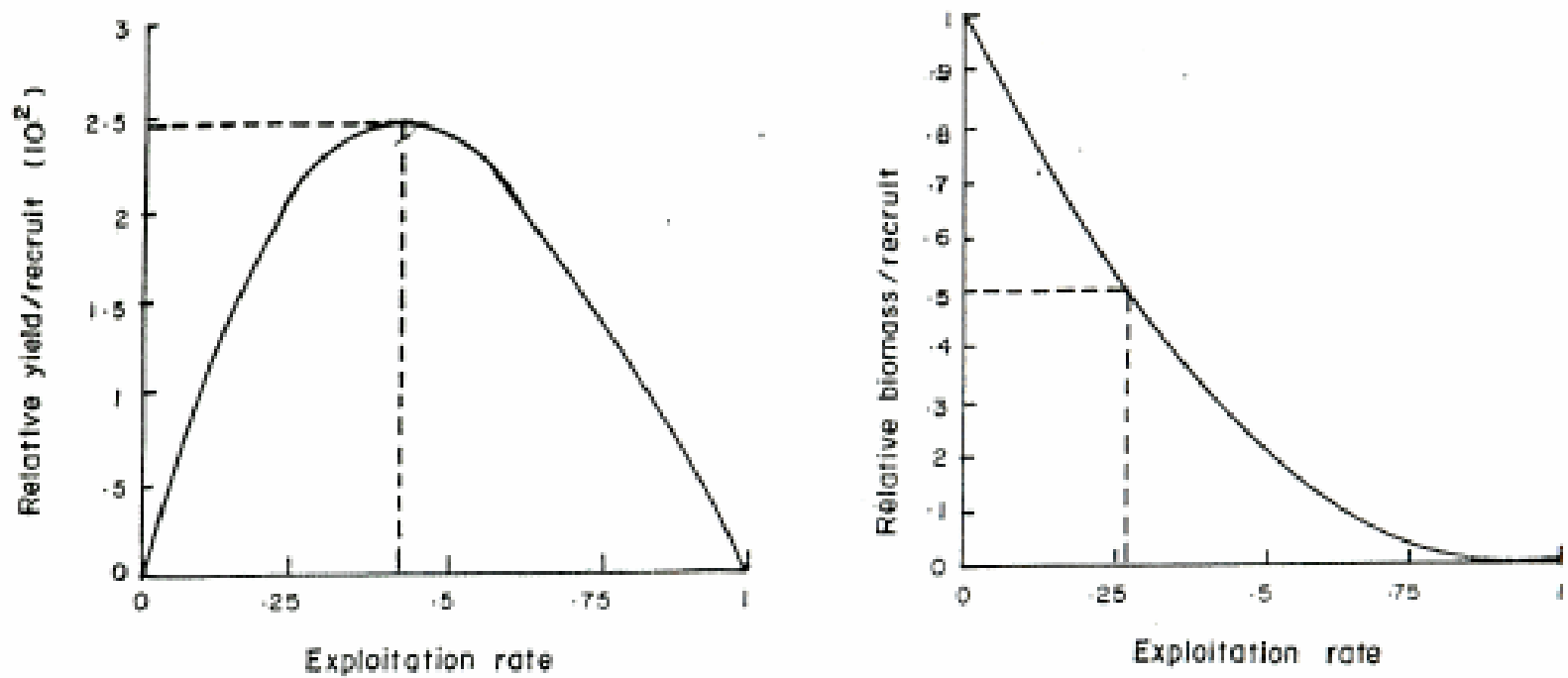

Fig. 10
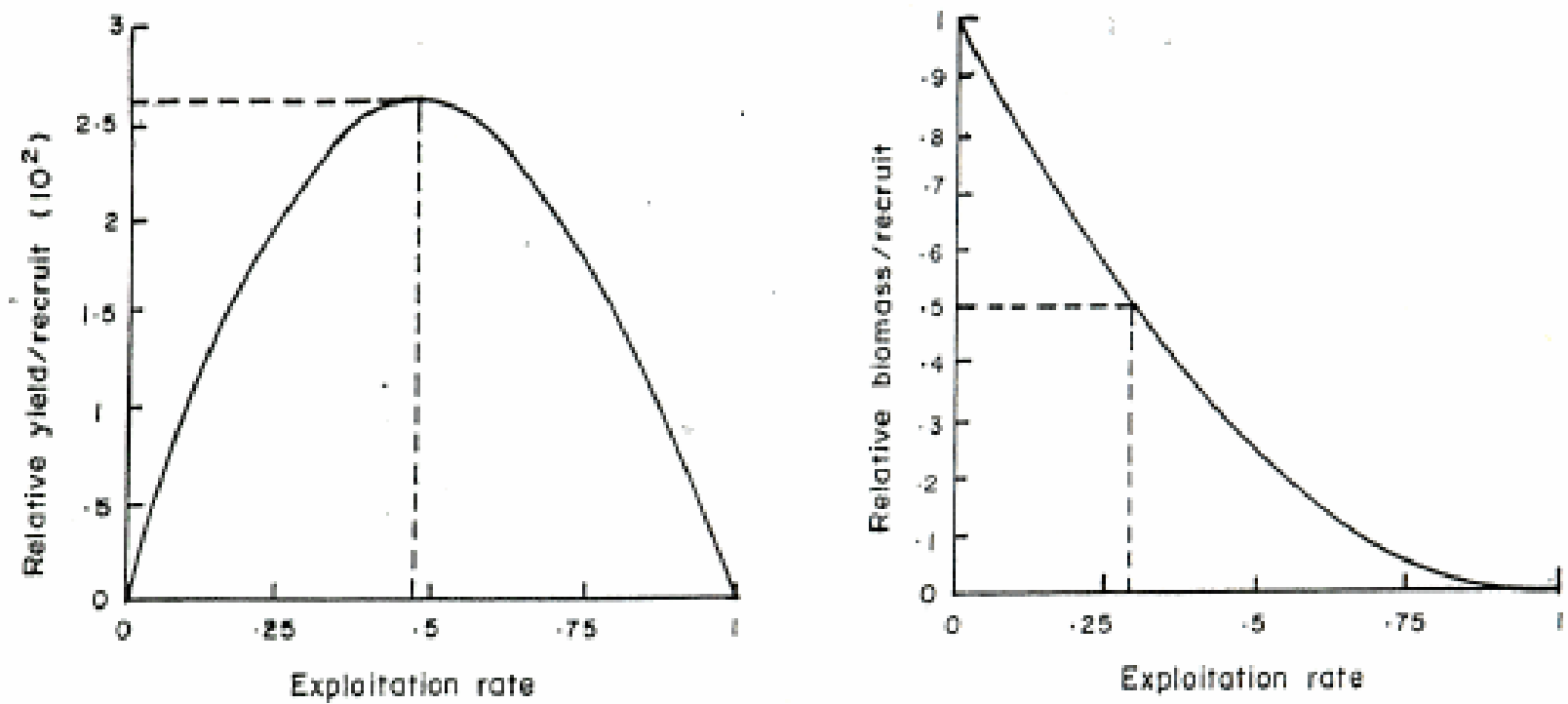

Fig. 10. Relative yield-per-recruit (left) and relative biomass-per-recruit (right) for M. vollenhovenii males of the Cross River Estuary, Nigeria, using the selection ogive option $\left(\mathrm{E}_{\max }=0.42, \mathrm{E}_{0.1}=0.4, \mathrm{E}_{0.5}=0.27\right)$.

Fig. 11. Relative yield-per-recruit (left) and relative biomass-per-recruit (right) for $M$. vollenhovenii females of the Cross River Estuary, Nigeria, using selection ogive option $\left.\left(\mathrm{E}_{\max }=0.47\right), \mathrm{E}_{0.1}=0.45, \mathrm{E}_{0.5}=0.29\right)$. 
www.wajae.org

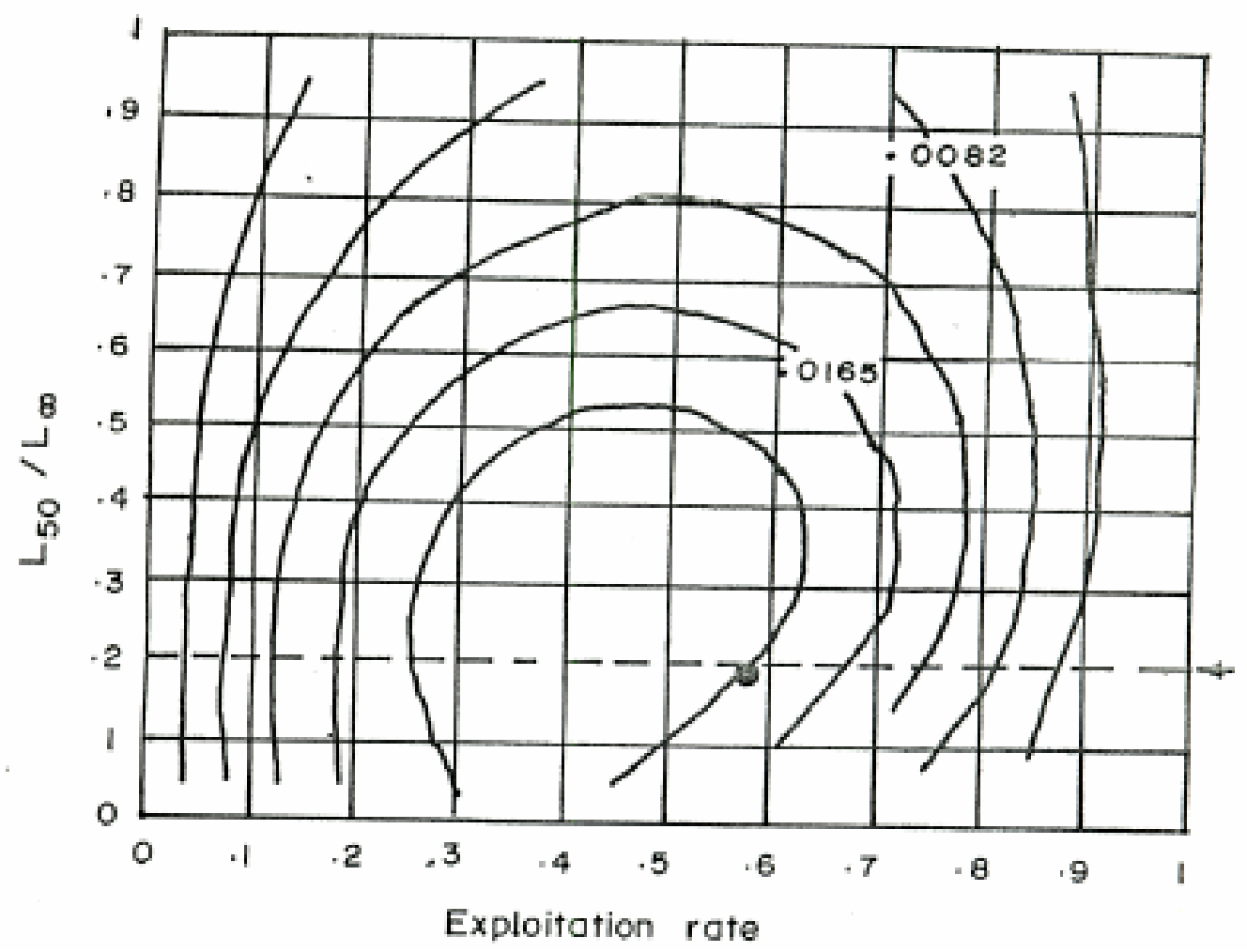

Fig. 12. Yield isopleths for M. vollenhovenii males of the Cross River Estuary, Nigeria, showing predicted response of relative yield-per-recruit of the shrimps to changes in length at first capture and exploitation rate. Arrow on the right ( 4 ) points to actual computed value of the critical ratio $\mathrm{L}_{c} \mathrm{~L} \infty=0.21$.

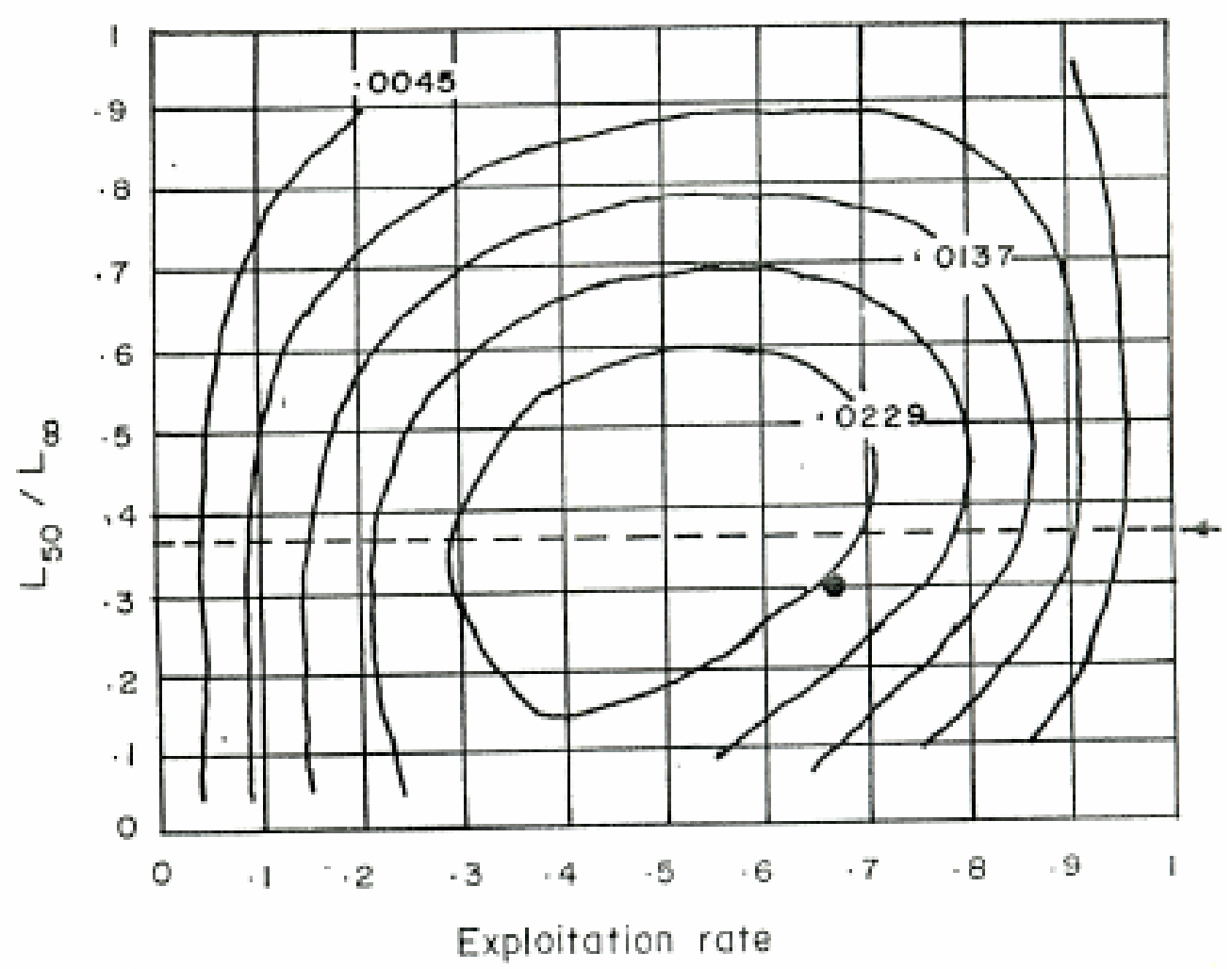

Volume 9 (Jan - Jun 2006)

Page 10 of 14 


\section{West Africa Journal of Applied Ecology (WAJAE) -ISSN: 0855-4307 \\ Volume 9 (Jan - Jun 2006) \\ www.wajae.org}

Fig. 13. Yield isopleths for $M$. vollenhovenii females of the Cross River Estuary, Nigeria, showing predicted response of relative yield-per-recruit of the shrimps to changes in length at first capture and exploitation rate. Arrow ( 4 ) on the right points to actual computed value of the critical ratio $L_{c} / L_{\infty}=0.37$.

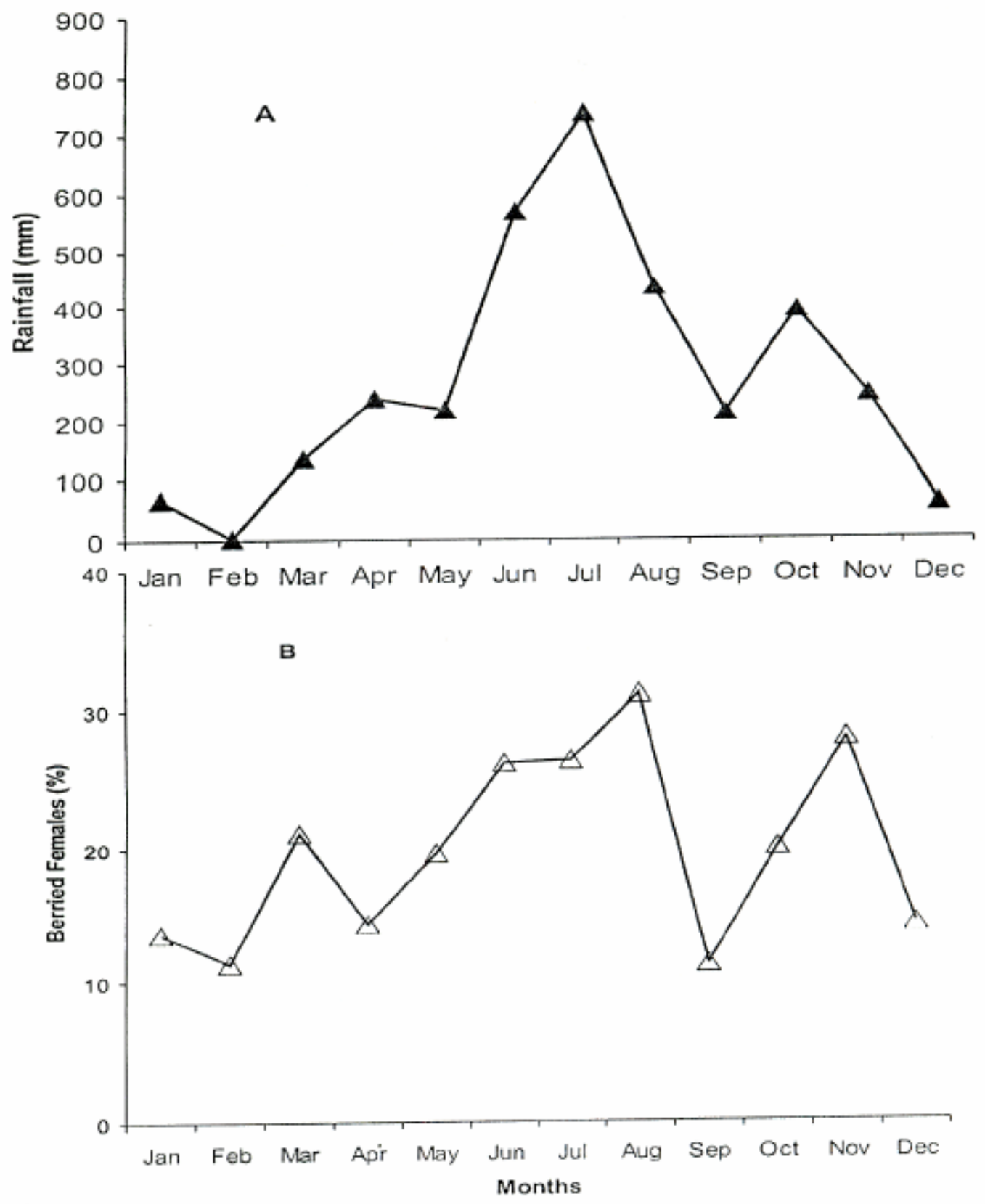

Fig. 14. A: Rainfall (mm) over Calabar in 1997; B: Monthly percentage of berried females of $M$. vollenhovenii in the Cross River Estuary in 1997.

\section{Discussion}

Asymptotic length $(\mathrm{L} \infty)$ is the largest theoretical size a species could attain should it grow indefinitely. This growth coefficient $\mathrm{K}$, as well as mortality rates are easily estimated using the ELEFAN routine of FiSAT. Pauly et al. (1984) first demons-trated applicability of ELEFAN routine to shrimp length-frequency data. Further, Sparre \& Venema (1992) showed that the growth of a cohort of crustaceans conforms to the von Bertalaffy growth function, hence justifying the use of length-frequency analysis tools of FiSAT for shrimps. 


\section{West Africa Journal of Applied Ecology (WAJAE) -ISSN: 0855-4307 \\ Volume 9 (Jan - Jun 2006) \\ www.wajae.org}

A sample size of 1,500 or more collected over a minimum period of 6 months is termed adequate by Pauly (1987). The sample size in this study met this requirement.

The estimated values of $\mathrm{L}$. and $\mathrm{K}$ for M. vollenhovenii $(21.4 \mathrm{~cm}$ and 1.24/year for males, and $19.8 \mathrm{~cm}$ and 1.25/year for females) differ from estimates of the species by Gabche \& Hockey (1995) and Etim \& Sankare (1998). These authors, however, did not separate the specimens in their study into sexes. While Gabche \& Hockey (1995) obtained L $\infty$ of $16.4 \mathrm{~cm}$ and K of 3.19/year, Etim \& Sankare (1998) obtained L $\infty$ of $18.0 \mathrm{~cm}$ and $\mathrm{K}$ of 0.81 year. Valenti et al. (1994) estimated $\mathrm{L} \infty$ and $\mathrm{K}$ of $21.0 \mathrm{~cm}$ and 0.493/year for another Macrobrachium species,

M. carcinus, in Brazil. The goodness of fit indices obtained in the study (0.199 and 0.183 for males and females, respectively) are rather low.

Isaac (1990) had demonstrated that growth parameters estimated from ELEFAN I could be biased as a result of individual growth variability, seasonal oscillations in growth, the restructuring procedure, sizedependent selection, variable recruitment period and large size-class interval. Using the growth performance index or phi prime ( $\Phi^{\prime}$ ') which is the basis of comparison of growth parameters (Moreau et al, 1986; Munro \& Pauly, 1983; Pauly, 1991) and which also takes into consideration $\mathrm{L}_{\infty}$ and $\mathrm{K}$, the results in this study fall within an acceptable range since the $\Phi^{\prime}$ values obtained in this study (2.75 and 2.67 for males and females) are comparable with those for $M$. carcinus (2.34) (Valenti et al. 1994), M. vollenhovenii (2.93) (Gabche \& Hockey 1995), and 2.47 (Etim \& Sankare, 1998). In contrast, the estimated longevity of the species varied widely from 11 months (Gabche \& Hockey, 1995) to 39.6 months (Etim \& Sankare, 1998).

The present study estimated longevity of 29.0 and 28.8 months, for $M$. vollenhovenii males and females, respectively. The amplitude of oscillation value of 0.95 observed for both sexes of $M$. vollenhovenii indicates that growth does strongly decrease in July for the males (WP $=0.6)$ and June for the females $(\mathrm{WP}=0.45)$. This falls within the reproductive period of the species, as well as the rainy season months characterized by low temperatures. The high C-value is also indicative of a temperature difference $\left(\mathrm{t}_{2}-\mathrm{t}_{1}\right)$ of about 10ÚC in the area (Longhurst \& Pauly, 1987), which is confirmed by Akpan \& Offem (1993) who obtained a temperature range of 21 ÚC (wet season) and $31^{\circ} \mathrm{C}$ (dry season) for the area. The weight growth for M. vollenhovenii was positively allometric for both sexes. This implies that the species growth pattern changes as it grows, a situation that may be connected with reproduction.

Year-round recruitment has been described to be a normal phenomenon for tropical fish and shrimp species (Qasim, 1973; Weber, 1976). While this was observed in the present study, M. vollenhovenii exhibited a major recruitment peak over the year's cycle in agreement with findings of Pauly \& Navaluna (1983) and Dwiponggo et al. (1986) for other short-lived species and as also confirmed for the same species in the Fahe River, Cote d'Ivoire. This main recruitment peak occurred at the same season in both sexes. The appearance of a second minor peak in females early in the year is difficult to explain. Perhaps both sexes segregate spatially with the result that female and male specimens of the same sizes are not at the same spot of the estuary. Length frequencies of the catches for both sexes would, thus, differ which would then be reflected in the recruitment pattern.

As short-lived species, high mortality rates are usually imperative. Enin (1995) obtained Z of 10.6/year, M of 3.36/year and F of 7.24/year for M. macrobrachion, Gabche \& Hockey (1995) obtained Z of 3.4061/year, M of 3.40/year, and F of 0.26/year, while Etim \& Sankare (1998) obtained Z of 3.69/year, M of 1.97/year and $\mathrm{F}$ of 1.72/year, both for $M$. vollenhovenii. Analysis of mortality using length-converted catch curves and Pauly's empirical equation (Eq.6), gave Z of 3.93/year and 6.85/year, M of 2.21/year and 2.27/year, F of 1.72/year and 4.58/year for $M$. vollenhovenii males and females, respectively. These gave exploitation rates (E) of 0.44 and 0.67 for the males and females respectively. On the contrary M. vollenhovenii in the Fahe reservoir had E of 0.47, while E of 0.07 was reported for the species in the Lobe River, Cameroon (Gabche \& Hockey, 1995). Going by Gulland (1971) rule of E $>0.5$ being suggestive of over-fishing, only the females of this species in the Cross River Estuary is presently being overexploited. Palacios et al. (1996) had also observed a sex- and size-related over-fishing for Penaeus stylirostrus. Possibly, female M. vollenhovenii have a higher vulnerability to the fishing gear than males due to behavioral differences related to egg bearing. They might occur in greater densities and/or have slower escape reactions when being fished.

Considering the relative yield-per-recruit analysis, the computed exploitation rate (E) of 0.44 for the males is slightly above the predicted maximum values of $\mathrm{E}_{\max }=0.42$, while that of the females, $\mathrm{E}=0.67$ is highly above the $\mathrm{E}_{\max }$ of 0.47 (selection ogive procedure). This again, confirms the high fishing pressure on the 


\section{West Africa Journal of Applied Ecology (WAJAE) -ISSN: 0855-4307 \\ Volume 9 (Jan - Jun 2006) \\ www.wajae.org}

females of this fishery. Using Pauly \& Soriano (1986) quadrants rule, the $\mathrm{L}_{\mathrm{c}} / \mathrm{L}_{\infty}$ ratio of 0.21 and $\mathrm{E}$ of 0.44 would place the males of this species into quadrant B. This implies an eumetric fishing situation, requiring no management interventions. By contrast, the yield isopleths giving an $\mathrm{L}_{c} / \mathrm{L} \infty$ ratio of 0.37 , and with $\mathrm{E}$ of 0.67, places the females in quadrant $\mathrm{C}$, which means that large shrimps are caught at high effort level. Here, exploitation rate should be reduced in order to fish at maximum $\mathrm{Y}^{\prime} / \mathrm{R}$. Since manage-ment is never done in isolation, reduction of effort is necessary to reduce exploitation rate of this fishery, and increase relative yieldper-recruit.

It is recommended that the fishing days in this fishery be reduced particularly during the reproductive period to enable more females to participate in the reproductive activity. Two peaks of reproduction were identified for the species (June-August, November-December). According to Akpan \& Offem (1993), plankton abundance in the area is highest from December- March (dry season). Hence, larvae spawned at this period are most favoured with respect to food availability. Therefore, a closure of the fishery, recommended here, should be implemented within the November-December reproductive period. Also, return of eggbearing females into the waters during the peak of reproduction should be adopted, and the fishermen should be encouraged to cooperate with this manage-ment option.

\section{Acknowledgement}

The authors thank the Forschungzentrum Jùlich Internationales Büro, Germany, who sponsored Dr F. M. Nwosu's study at the Center for Tropical Marine Ecology (ZMT) Bremen, Germany.

\section{References}

Akpan E. R. and Offem J. O. (1993). Seasonal variation in water quality of the Cross River, Nigeria. Rev. Hydrobiol. Trop. 26(2): 95-103.

Bello-Olusoji O. A. and Somers M. J. (1997). Assessment of the African River Prawn Macrobrachium vollenovenii (Herklots, 1857) in some lentic and lotic environments in Nigeria. Afr. J. Ecol. 35(1): 80-81.

Bertalanffy L. Von (1938). A quantitative theory of organic growth (inquiries in growth laws II). Hum. Biol. 10: 181-213.

Beverton R. J. H. and Holt S. J. (1964). Tables of yield functions for fishery assessment. FAO Fish. Tech. Pap. $38: 49$ pp.

Dwiponggo A., Hariati T., Banon S., Palomares M. L. and Pauly D. (1986). Growth, mortality and recruitment of commercially important fishes and Penaeid shrimps in Indonesian waters. ICLARM Tech. Rep. 17: 91 pp.

Enin U. I. (1995). First estimates of growth, mortality and recruitment parameters of Macrobrachium macrobrachion Herklots, 1851 in the Cross River Estuary, Nigeria. Dana 11(1): 29-38.

Etim L. and Sankare Y. (1998). Growth and mortality, recruitment and yield of the freshwater shrimp, Macrobrachium vollenhovenii Herklots, 1857 (Crustacea, Palaemonidae) in Fahe Reservoir, Cote d’Ivoire, West Africa. Fish. Res. 38: 211-223.

FAO (2000). Aquaculture production statistics 1989-1998. FAO Fisheries Circular 815 (rev. 12). FAO, Rome.

Gabche C. E. and Hockey H. U. P. (1995). Growth and mortality of the giant African River Prawn, Macrobrachium vollenhovenii (Herklots: Crustacea, Palaemonidae) in the Lobe River, Cameroon: A Preliminary evaluation. J. Shellfish. Res. 14(1): 185-190.

Gayanilo Jr. F. C. J and Pauly D. (ed.) (1997). FAO-ICLARM Stock Assessment Tools (FiSAT). Reference manual. FAO Computerized Informa-tion Series (Fisheries), No. 8. Rome, FAO. 262 pp.

Gulland J. A. (1971). The fish resources of the ocean. West Byfleet, Surrrey. Fishing News Books Ltd, FAO. 255 pp.

Gulland J. A. (1982). The management of tropical multi-species fisheries. In Theory and management of tropical fisheries. (D. Pauly and G. I. Murphy ed.), pp. 287-298. ICLARM Conf. Proc.

Isaac V. J. (1990). The accuracy of some length-based methods for fish population studies. ICLARM Tech. Rep. No. 27: 81 pp.

Longhurst A. R. and Pauly D. (1987). Ecology of tropical oceans. Academic Press, San Diego, Calif. 407 pp.

Marioghae I. E. (1982). Notes on the biology and distribution of Macrobrachium vollenhovenii and Macrobrachium macrobrachion in the Lagos lagoon (Crustacea, Decapoda, Palaemonidae). Rev. Zool. Afr. 94(3): 493-508.

Moreau J. and Cuende F.X. (1991). On improving the resolution of the recruitment patterns of fishes. Fishbyte 9(1): 45-46.

Moreau J., Bambino C. and Pauly D. (1986). Indices of overall growth performance of 100 Tilapia (Cichlidae) populations. In The First Asian Fisheries Forum. Asian Fisheries Society, Manila (J. L. Maclean, L. B. Dizon and L. V. Hosillos ed.), pp. $201-206$.

Munro J. L. and Pauly D. (1983). A simple method for comparing the growth of fishes and invertebrates. Fishbyte 1(1): 5-6.

New M. B. and Singholka S. (1985). Freshwater prawn farming: a manual for the culture of Macrobrachium rosenbergii. FAO Fisheries Technical Paper Rev. 1(225): 118 pp.

Nwosu F. M. (2000). Studies on the biology, ecology and fishery impact on the Macrobrachium species o the Cross River Estuary, Nigeria. (PhD Thesis.), University of Calabar, Calabar, Nigeria. 224 pp.

Palacios J. A., Angulo R. and Rodriguez J. A. (1996). The Penaeus stylirostris (Decapoda, Penaeidae) fishery in the Gulf of Nicoya, Costa Rica. Rev. Biol. Trop. 44(1): 225-231.

Pauly D. (1980a). A selection of simple methods for the assessment of tropical fish stocks. FAO Fish. Cir. $729: 54$ pp.

Pauly D. (1980b). On the interrelationships between natural mortality, growth parameters and mean environmental temperature in 175 fish stocks. J. Cons. ICFM 39(3): 175-192.

Pauly D. (1983). Length-converted catch curves: A powerful tool for fisheries research in the tropics (Part 1). Fishbyte 1(2): 9-13.

Pauly D. (1984). Fish population dynamics in tropical waters: a manual for programmable calculators. ICLARM Study Rev. 8: 325 pp. 


\section{West Africa Journal of Applied Ecology (WAJAE) -ISSN: 0855-4307 \\ Volume 9 (Jan - Jun 2006) \\ wWw.wajae.org}

Pauly D. (1985). On improving operation and use of the ELEFAN Programs. Part 1: avoiding drift of K towards low values. Fishbyte 3(3): 13-14.

Pauly D. (1987). A review of the ELEFAN system for analysis of length-frequency data in fish and aquatic invertebrates. In Lengthbased methods in fisheries research. (D. Pauly and R. Morgan ed.), pp. 7-34. ICLARM Conf. Proc. 13.

Pauly D. (1991). Growth performance in fishes: Rigorous description of patterns as a basis for understanding causal mechanisms. Aquabyte 4(3): 3-6.

Pauly D. and David N. (1981). ELEFAN I, a basic program for the objective extraction of growth parameters from length-frequency data. Meerestorschiung 28(4): 205-211.

Pauly D. and Gaschütz G. (1979). A simple method for fitting oscillating length growth data, with a program for pocket calculators. Int. Cons. Explor. Sea Demersal Fish Comm. 1979/G/24, 26 pp.

Pauly D. and Munro J. L. (1984). Once more on the comparison of growth in fish and invertebrates. Fishbyte 2(1): 21.

Pauly D. and Navaluna N. A. (1983). Monsoon-induced seasonality in recruitment of Philippine fishes. FAO Fish. Rep. 3(291): 823-833.

Pauly D. and Soriano, M. L. (1986). Some practical extensions to Beverton and Holt's relative yield-per-recruit model. In The First Asian Fisheries Forum. (J. L. MacLean, L. B. Dixon and L. V. Hosillo, ed.), pp. 491-496. Asian Fisheries Society, Manila, Philippines.

Pauly D., Ingles J. and Neal R. (1984). Application to shrimps of objective methods for the estimation of growth, mortality and recruitment parameters from length-frequency data. (ELEFAN I and II). In Penaeid shrimps - Their Biology and Management. (J. A. Gulland and B. Rothschild ed.), pp. 220-234. Fishing News Books, UK.

Powell C. B. (1983). Fresh and brackish water shrimps of economic importance in the Niger Delta. In Proceedings of Second Annual Conference of the Fisheries Society of Nigeria, Calabar. pp. 254-284.

Qasim S. Z. (1973). Some implications of the problem of age and growth in marine fishes from Indian waters. Indian J. Fish. 20(3): 351-371.

Sparre P. and Venema S. C. (1992). Introduction to tropical fish stock assessment. Part I. Manual. FAO Fish. Tech. Pap. 306(1): 376 pp.

Taylor C. C. (1958). Cod growth and temperature. J. Cons. Inter. Explor. Mer. 23: 366-370.

Valenti W.C., De T. C., De-Mello J. and Labao V. L. (1994). Maturation and growth curves of Macrobrachium carcinus (Linnaeus) (Crustacea, Decapoda, Palaemonidae) from Ribeira de Iguape River, Southern Brazil. Rev. Bras. Zool. 11(4): 649-658.

Weber W. (1976). The influence of hydrographic factors on the spawning time of tropical fish. In Fisheries Resources and their Management in Southeast Asia. (K. Tiews, ed.), pp. 269-281.

Willführ-Nast J., Rosenthal H., Udo P. J. and Nast F. (1993). Laboratory cultivation and experimental studies of salinity effects on larval development in the African river prawn, Macrobrachium vollenhovenii (Decapoda, Palaemonidae). Aquat. Living Resour. 6: 115-137. 